UDK $577.1: 61$

ISSN 1452-8258

J Med Biochem 37: 406-414, 2018

Original paper

Originalni naučni rad

\title{
B-TYPE NATRIURETIC PEPTIDE AS A MARKER OF DIFFERENT FORMS OF SYSTEMIC SCLEROSIS
}

\author{
B-TIP NATRIURETSKOG PEPTIDA KAO MARKER \\ RAZLIČITIH OBLIKA SISTEMSKE SKLEROZE
}

\author{
Jelena Stefanović Nešković1, Anđelka Ristić2, Milan Petronijević3, Aleksandra Zeljković4, \\ Aleksandra Grdinić, Ognjen Gudelj ${ }^{1}$, Branka Đurović6 ${ }^{6}$, Branimir Nešković $^{7}$ \\ ${ }^{1}$ Clinic for Cardiology, Military Medical Academy, Belgrade, Serbia \\ ${ }^{2}$ Clinic for Emergency and Internal Medicine, Military Medical Academy, Belgrade, Serbia \\ ${ }^{3}$ Clinic for Rheumatology, Military Medical Academy, Belgrade, Serbia \\ ${ }^{4}$ Department of Medical Biochemistry, Faculty of Pharmacy, University of Belgrade \\ ${ }^{5}$ University Hospital Northern Norway, Medical Department, Norway \\ ${ }^{6}$ Institute of Occupational Medicine, Medical Academy, Belgrade, Serbia \\ ${ }^{7}$ Clinic for General Surgery, Military Medical Academy, Belgrade, Serbia
}

\section{Summary}

Background: Systemic sclerosis (SSc) is an autoimmune connective tissue disease which affects various tissues and organs, including skin, lungs, kidneys, gastrointestinal tract and cardiovascular system. Cardiac involvement is the most commonly recognized problem and a significant cause of morbidity. The brain natriuretic peptide (BNP) is a previously known marker of elevated cardiovascular risk in SSc, but the levels of BNP in various forms of SSc have not been investigated so far.

Aim: The aim of our study was to evaluate the influence of $\mathrm{SSc}$ on the function of the right ventricle and the right atrium using the echocardiographic parameters. Moreover, we examined the levels of BNP in different forms of SSc as well as the association of disease severity with the plasma concentrations of BNP.

Methods: We included 42 patients with newly diagnosed SSc and patients whose disease had been diagnosed earlier. SSc patients and non-SSc control patients were examined by using echocardiography and the concentrations of BNP were determined.

Results: We analyzed differences in the parameters of right ventricle (RV) function and right atrium (RA) function between SSc patients and healthy controls. The two groups

\section{Kratak sadržaj}

Uvod: Sistemska skleroza (SSc) jeste autoimuna bolest vezivnog tkiva koja utiče na različita tkiva i organe, uključujući kožu, pluća, bubrege, gastrointestinalni trakt i kardiovaskularni sistem. Komplikacije na srcu su najčešće prepoznat problem i značajan uzrok morbiditeta. Moždani natriuretski peptid (BNP) odranije je poznat marker povišenog kardiovaskularnog rizika u SSc, ali nivoi BNP-a u različitim formama SSc do sada nisu ispitivani.

Cilj: Cilj naše studije bio je proveriti uticaj SSc na funkciju desne komore i desne pretkomore praćenjem ehokardiografskih parametara. Takođe, ispitivali smo koncentracije BNP-a u različitim formama SSc.

Metode: U studiju je uključeno 42 bolesnika sa novootkrivenom SSc, kao i bolesnici kod kojih je bolest ranije dijagnostikovana. Bolesnicima sa SSc i kontrolnoj grupi obavljen je ultrazvučni pregled srca i određena koncentracija BNP-a. Rezultati: Analizirali smo razlike u parametrima funkcija desne komore i desne pretkomore između bolesnika sa SSc i zdravih osoba. Zadebljanje zida desne komore je veće kod bolesnika sa SSc $(p<0,001)$, dok se površine desne komore u sistoli $\left(\operatorname{RV}_{E S A} ; \mathrm{p}=0,408\right)$ i dijastoli $\left(R V_{E D A}\right.$; $\mathrm{p}=0,368$ ) ne razlikuju među ispitanicima. Nasuprot tome, veličina desne pretkomore - kratke ose na kraju dijastole

Address for correspondence:

Jelena Stefanović Nešković

UI. Vojvode Vlahovića 41B, Zvezdara, Beograd

Mob: 0631899499

e-mail: stefanovic.jelena1@gmail.com 
had similar distribution of gender, but SSc patients were significantly older than controls. RV wall thickness was increased in SSc patients $(p<0.001)$, while right ventricular end-systolic area $\left(\mathrm{RV}_{E S A} ; \mathrm{p}=0.408\right)$ and right ventricular end-diastolic area $\left(R V_{E D A} ; p=0.368\right)$ did not differ among the examinees. In contrast, RA minor-axis dimension $(p=0.001)$ and the tricuspid annular plane systolic excursion (TAPSE) $(p=0.001)$ were significantly higher in SSc patients. Also, we analyzed differences in brain natriuretic peptide (BNP) concentrations between diffuse cutaneous systemic sclerosis (DSSc) and limited cutaneous systemic sclerosis (LSSc) patients. DSSc patients had significantly higher concentrations of BNP. We found that levels of BNP were in significant positive correlations with age $(p=0.007)$, disease duration $(p=0.023), C$ reactive protein (CRP) $(p=0.032)$, right ventricle fractional area change (FAC) $(p=0.022)$, pulmonary vascular resistance (PVR) and Rodnan score $(p=0.019)$.

Conclusions: Given the obtained results, the laboratory determination of BNP could be useful in differentiating different forms of systemic sclerosis as well as in predicting the severity of the disease and future cardiovascular complications.

Keywords: systemic sclerosis, right ventricle, right atrium, brain natriuretic peptide (BNP), capillaroscopy, Rodnan score

\section{Introduction}

Systemic sclerosis (SSc) is an autoimmune connective tissue disease which affects various tissues and organs, including skin, lungs, kidneys, gastrointestinal tract and cardiovascular system (1). There are two subtypes of SSc, i.e., diffuse cutaneous SSc (skin thickening also involves the extremities proximal to elbows and knees, chest, abdomen and back) and limited cutaneous SSc (skin thickening is localized to the face, neck and extremities distal to elbows and knees) (2). Cardiac involvement is the most commonly recognized problem and a significant cause of morbidity (3). The presence of cardiac events is a bad prognostic sign and is one of the leading causes of mortality in patients with SSc (4-6). The brain natriuretic peptide (BNP) is a previously known marker of elevated cardiovascular risk in SSc, but the levels of $\mathrm{BNP}$ in various forms of SSc have not been investigated so far.

Cardiac involvement can be primary and secondary. Primary cardiac involvement, which develops as a direct consequence of SSc, may manifest as myocardial involvement, fibrosis of the conduction system, pericardial and less frequently, as valvular disease (2). Secondary cardiac involvement may manifest as a consequence of pulmonary arterial hypertension $(\mathrm{PAH})$, interstitial lung disease and kidney disease $(7,8)$.

For the detection of myocardial damage in patients with SSc, in everyday clinical work a large number of noninvasive methods is used, but the most accessible are electrocardiography and echocardiography $(9,10)$. For many years, the right ventricle $(p=0,001)$ i sistolni pomak lateralnog dela trikuspidnog prstena prema vrhu srca (TAPSE) $(p=0,001)$ značajno su veći kod bolesnika sa SSc. Takođe, analizirali smo razlike u koncentraciji BNP-a između bolesnika sa difuznom sistemskom sklerozom (DSSc) i lokalizovanom sistemskom sklerozom (LSSc). DSSc bolesnici su imali značajno veće koncentracije BNP-a. Nivo BNP-a bio je u značajnoj pozitivnoj korelaciji sa starošću $(p=0,007)$, trajanjem bolesti $(p=0,023)$, $C$ reaktivnim proteinom (CRP) $(p=0,032)$, frakcionim skraćenjem desne komore (FAC) $(p=0,022)$, plućnom vaskularnom rezistencijom (PVR) $(p=0,042)$ i Rodnan skorom $(p=0,019)$.

Zaključak: $\mathrm{S}$ obzirom na dobijene rezultate, laboratorijsko određivanje BNP-a moglo bi biti korisno u diferencijaciji različitih oblika sistemske skleroze, kao i u predviđanju težine bolesti i budućih kardiovaskularnih komplikacija.

Ključne reči: sistemska skleroza, desna komora, desna pretkomora, BNP, kapilaroskopija, Rodnan skor

(RV) has been considered less relevant in cardiac diseases than the left ventricle (11). Nowadays, it is considered that the RV function markers can be used for management and prognosis of many cardiac diseases, such as congestive heart failure, arrhythmia and sudden cardiac death $(12,13)$. Echocardiography is an available, noninvasive technique, less expensive than the other techniques and is used for evaluation of RV function. Upon the recommendation of The European Heart Association, echocardiography should be done annually for asymptomatic SSc patients and patients with symptomatic connective tissue disease (14).

The role of clinical chemistry laboratory in diagnosis and monitoring of SSc is largely underestimated. However, recently brain natriuretic peptide (BNP) and $\mathrm{N}$-terminal proBNP (NT-proBNP) were proposed as the latest useful markers in the prediction of cardiovascular outcome in SSc (15-17). Brain natriuretic peptide (BNP) is a natriuretic hormone that is initially identified in the brain but released primarily from the heart, in particular the ventricles.

Recent studies suggest that the functions of the right and left ventricle have been reduced in SSc patients and they are associated with morbidity. It has been proven that measurements of the systolic function of the right ventricle, such as the mobility of the tricuspid annular plane systolic excursion (TAPSE), the right ventricle fractional area change (FAC), an indicator of RV myocardial contractility via the TEI index, $\mathrm{S}$ wave, correlate with reduced survival. It is known that an enlarged right atrium and right ventricle in SSc patients are directly related to the symp- 
toms and the signs of heart failure and mortality. The right atrium size is correlated with the cardiac involvement in pulmonary arterial hypertension (PAH) (4-6, 9 ). Yet, it is still unclear whether BNP has any potential in clustering patients according to the form and severity of SSc.

The aim of our study was to evaluate the influence of SSc on the function of the right ventricle and right atrium using the echocardiographic parameters. Moreover, we examined the levels of BNP in different forms of SSc as well as the association of disease severity with the BNP plasma concentration.

\section{Materials and Methods}

We included 42 patients with the newly diagnosed SSc and patients whose disease had been diagnosed earlier. The testing was conducted in the Clinic for Emergency Internal Medicine and Clinic for Rheumatology of the Military Medical Academy in 2016. A total of 42 patients with SSc were diagnosed as SSc according to the American College of Rheumatology (ACR) classification criteria for SSc (18). The exclusion criteria were asthma, chronic obstructive bronchitis, patients without known cardiovascular and pulmonary disease.

SSc patients and non-SSc control patients were examined by using echocardiography performed by a single cardiologist. Conventional echocardiographic examinations were performed using a Phillips iE-33 system. All parameters were measured according to the published recommendations.

The following parameters were investigated:

- Measurement of the RV dimensions: RV wall thickness, right ventricular end-systolic area $\left(\mathrm{RV}_{\mathrm{ESA}}\right)$ and right ventricular end-diastolic area $\left(R V_{E D A}\right)$ and 2D fractional area change (FAC),

- Analysis of blood flow through the tricuspid valve during diastole: early diastolic filling velocity $\left(E_{t z}\right)$, late diastolic filling velocity $\left(A_{t z}\right), E_{t z}$ to $A_{t z}$ ratio, deceleration time (DT),

- TAPSE (the tricuspid annular plane systolic excursion), right ventricular systolic pressure (RVSP) based on peak tricuspid regurgitant velocity (TRVmax),

- Inferior vena cava diameter ( $\mathrm{VCl})$.

- Pulmonary vascular resistance (PVR) was noninvasively estimated utilizing the Abbas equation: (tricuspid regurgitant velocity/ time velocity integral of the RV outflow tract $\times 10+0.16)$ with an abnormal value defined as $>2.0$ Wood Units (WU) (19).

- The tricuspid annular velocities were determined by pulsed wave Doppler tissue: peak early velocity $\left(e^{\prime}\right)$, peak late diastolic velocity $\left(a^{\prime}\right), e^{\prime} / a^{\prime}$ ratio, the ratio of early diastolic tricuspid inflow to tricuspid lateral annular velocity (tricuspid $\left.E_{t z} / e^{\prime}\right)$, velocity of the tricuspid annular systolic motion $\left(s^{\prime}\right)$.

- The TEI index or myocardial performance index (MPI) is an indicator of RV myocardial contractility. It is defined as the ratio of total isovolumic time divided by ejection time (ET) (19). It is calculated using the following formula: $\mathrm{MPI}=($ IVRT + IVCT)/ET.

Capillaroscopy is a simple, safe and painless method for evaluating small vessels of the microcirculation (20). The importance of capillaroscopy as a noninvasive diagnostic method is in early detection of abnormalities in capillary morphology, monitoring the progression of systemic disease and involvement of internal organs. The abnormalities can be observed long before the onset of clinical symptoms (21). In most SSc patients, peripheral microangiopathy follows a typical scleroderma pattern, consisting of 'early', 'active' and 'late' phases (22). The "early" pattern can be detected many years before the complete clinical manifestation of SSc, and the progression to "active" and "late" patterns corresponds to internal organ involvement (23). Capillaroscopy as a diagnostic method is significant because it is included in the EULAR classification criteria of SSc (24).

Plasma levels of BNP were determined by a commercially available immunoassay on an automated platform (ADVIA Centaur BNP assay; Siemens Healthcare Diagnostics Inc, Tarrytown, NY, USA). The Advia Centaur BNP assay measures BNP concentrations up to $5000 \mathrm{pg} / \mathrm{mL}$ (1445 pmol/L) with a minimum detectable concentration (analytical sensitivity) of $<2.0 \mathrm{pg} / \mathrm{mL}(0.58 \mathrm{pmol})$. The functional sensitivity is defined as the lowest BNP concentration determined at a coefficient of variation of $20 \%$. The ADVIA Centaur BNP assay functional sensitivity was determined to be $2.5 \mathrm{pg} / \mathrm{mL}(0.72 \mathrm{pmol} / \mathrm{L})$. The intraassay coefficient of variation is $4.3 \%$ "within-run « and $1.9 \%$ »run-to-run« at $29.4 \mathrm{pg} / \mathrm{mL}, 2.5 \%$ »within-run« and $2.1 \%$ »run-to-run« at $48.5 \mathrm{pg} / \mathrm{mL}, 1.8 \%$ »withinrun« and 1.9\% »run-to-run« at $410 \mathrm{pg} / \mathrm{mL}, 2.0 \%$ "within-run« and 1.5\% »run-to-run« at $458 \mathrm{pg} / \mathrm{mL}$, $2.0 \%$ "within-run« and $0.5 \%$ »run-to-run« at 1452 $\mathrm{pg} / \mathrm{mL}$ and $2.1 \%$ »within-run« and $1.7 \%$ »run-to-run« at $1736 \mathrm{pg} / \mathrm{mL}$. A reference range for BNP is defined as the interval between 2.00 and $32.80 \mathrm{pg} / \mathrm{mL}$.

The modified Rodnan skin score (MRSS) is a measure of skin thickness and measure of disease severity and mortality in patients with dcSSc (25). An increase in skin thickening is associated with increased risk of the internal organs' involvement and increased mortality (26).

This observational cross-sectional study was approved by the Ethics Committee of the Institutional Review Board (IRB) of the Military Medical Academy 
and written informed consent was given by the patients. This study complies with the World Medical Association's Declaration of Helsinki.

\section{Statistical analysis}

Variables that followed normal distribution were presented as mean \pm standard deviation (Sd) and compared by the Student-t test or ANOVA. Asymmetrically distributed variables were presented as median (interquartile range) and analyzed by MannWhitney U-test. Chi-square test - contingency tables were employed for analysis of categorical variables, presented as absolute frequencies. Correlation analysis was performed by using Spearman's test. Differences with $\mathrm{P}<0.05$ were considered to be statistically significant. Exploration of differences in BNP levels among patients divided according to the results of capillaroscopy was done by the Kruskal-Wallis test following post hoc Mann-Whitney U-test. The Bonferroni correction was used in order to reduce a likelihood of type I error. According to the Bonferroni adjustment, statistical significance for multiple comparison testing was set at $P<0.017$. All statistical analyses were done by employing PASW Statistics version 18.0 and MedCalc Software version 11.4.

\section{Results}

In this study, we included 42 patients with SSc aged 34-71 years (mean: 51.52; Sd: 10.63) and 40 non-SSc control patients aged $21-62$ years (mean: 39.40; Sd: 9.95) without known cardiovascular and pulmonary disease. SSc patients were predominantly women. Six patients were men and 36 were women.

In Table I, we presented the results of analysis of differences in parameters of RV function between SSc

Table I Parameters of right ventricular function in SSc patients and healthy controls.

\begin{tabular}{|c|c|c|c|}
\hline & $\operatorname{SSc}(n=42)$ & Controls $(n=40)$ & $P$ \\
\hline Age (years) & $51.52 \pm 10.63$ & $39.40 \pm 9.95$ & $<0.001$ \\
\hline Gender, male (n) & 6 & 11 & 0.177 \\
\hline RV wall thickness $(\mathrm{cm})^{\#}$ & $0.40(0.40-0.51)$ & $0.35(0.30-0.98)$ & $<0.001$ \\
\hline $\mathrm{RV}_{\mathrm{ESA}}(\mathrm{mm})$ & $5.55(4.50-8.25)$ & $5.90(4.38-6.90)$ & 0.408 \\
\hline $\mathrm{RV}_{\mathrm{EDA}}(\mathrm{mm})$ & $10.50(9.23-13.53)$ & $12.20(9.40-13.08)$ & 0.368 \\
\hline FAC (\%) & $49.15 \pm 12.87$ & $48.80 \pm 8.82$ & 0.888 \\
\hline RA major-axis dimension $(\mathrm{cm})$ & $4.45 \pm 0.56$ & $4.33 \pm 0.49$ & 0.295 \\
\hline RA minor-axis dimension $(\mathrm{cm})$ & $3.48 \pm 0.42$ & $3.19 \pm 0.36$ & 0.001 \\
\hline TAPSE $(\mathrm{cm})$ & $2.47 \pm 0.39$ & $2.21 \pm 0.33$ & 0.001 \\
\hline $\mathrm{E}_{\mathrm{tz}}(\mathrm{cm} / \mathrm{s})^{\#}$ & $55.90(46.90-59.55)$ & $56.80(53.88-62.40)$ & 0.021 \\
\hline $\mathrm{A}_{\mathrm{tz}}(\mathrm{cm} / \mathrm{s})^{\#}$ & $38.00(35.08-39.83)$ & $44.25(41.53-49.53)$ & $<0.001$ \\
\hline $\mathrm{E}_{\mathrm{tz}} / \mathrm{A}_{\mathrm{tz}}^{\#}$ & $1.40(1.30-1.70)$ & $1.30(1.14-1.38)$ & 0.001 \\
\hline $\mathrm{E}_{\mathrm{t} z} / \mathrm{e}^{\prime \#}$ & $5.20(4.19-6.35)$ & $4.60(4.10-4.90)$ & 0.017 \\
\hline $\mathrm{s}^{\prime}(\mathrm{cm} / \mathrm{s}){ }^{\#}$ & $12.90(11.48-15.70)$ & $12.00(11.33-12.68)$ & 0.007 \\
\hline $\mathrm{e}^{\prime}(\mathrm{cm} / \mathrm{s})^{\#}$ & $10.80(8.19-14.18)$ & $12.10(10.53-12.70)$ & 0.148 \\
\hline$a^{\prime}(\mathrm{cm} / \mathrm{s})^{\#}$ & $13.20(11.85-15.80)$ & $9.35(8.70-10.10)$ & $<0.001$ \\
\hline $\mathrm{e}^{\prime} / \mathrm{a}^{\prime \#}$ & $0.70(0.50-0.95)$ & $1.10(0.90-1.30)$ & $<0.001$ \\
\hline $\mathrm{DT}(\mathrm{ms})^{\#}$ & $193.00(159.50-232.00)$ & $204.50(160.00-216.75)$ & 0.981 \\
\hline$T R \operatorname{Vmax}(\mathrm{cm} / \mathrm{s})^{\#}$ & $2.51(2.13-2.78)$ & $2.02(1.76-2.32)$ & 0.001 \\
\hline $\mathrm{RVSP}(\mathrm{mm} \mathrm{Hg})$ & $33.51 \pm 8.71$ & $28.80 \pm 4.42$ & 0.003 \\
\hline $\mathrm{VCl}(\mathrm{cm})^{\#}$ & $1.50(1.13-1.70)$ & $1.19(1.02-1.56)$ & 0.005 \\
\hline PVR $\left(\mathrm{MPa} \times \mathrm{s} / \mathrm{m}^{3}\right)^{\#}$ & $1.56(1.28-1.99)$ & $1.22(1.14-1.30)$ & $<0.001$ \\
\hline TEl index ${ }^{\#}$ & $0.40(0.30-0.43)$ & $0.30(0.30-0.40)$ & 0.090 \\
\hline
\end{tabular}

Data are presented as mean \pm Sd for continuous variables, or as absolute frequencies for categorical variables and compared by the Student's t-test or by the Chi-square test, respectively. \#Due to asymmetrical distribution, values are presented as median (interquartile range) and analyzed by the Mann-Whitney U-test. 
Table II Parameters of right ventricular function in DSSc and LSSc patients.

\begin{tabular}{|c|c|c|c|}
\hline & DSSc $(n=17)$ & LSSc $(n=25)$ & $\mathrm{P}$ \\
\hline Age (years) & $52.06 \pm 9.52$ & $51.16 \pm 11.51$ & 0.792 \\
\hline Gender, male ( $n$ ) & 6 & 0 & 0.002 \\
\hline RV wall thickness $(\mathrm{cm})^{\#}$ & $0.40(0.38-0.53)$ & $0.40(0.40-0.55)$ & 0.252 \\
\hline $\mathrm{RV}_{\mathrm{ESA}}(\mathrm{mm})$ & $5.60(4.55-8.15)$ & $5.50(4.46-8.30)$ & 0.635 \\
\hline $\mathrm{RV}_{\mathrm{EDA}}(\mathrm{mm})$ & $10.10(9.01-15.00)$ & $10.70(9.50-13.30)$ & 0.808 \\
\hline FAC (\%) & $49.82 \pm 11.61$ & $48.67 \pm 13.92$ & 0.781 \\
\hline RA major-axis dimension & $4.45 \pm 0.62$ & $4.45 \pm 0.54$ & 0.978 \\
\hline RA minor-axis dimension & $3.52 \pm 0.34$ & $3.45 \pm 0.47$ & 0.606 \\
\hline TAPSE $(\mathrm{cm})$ & $2.44 \pm 0.47$ & $2.49 \pm 0.33$ & 0.670 \\
\hline $\mathrm{E}_{\mathrm{tz}}(\mathrm{cm} / \mathrm{s})^{\#}$ & $51.40(46.40-58.65)$ & $56.80(47.70-62.70)$ & 0.159 \\
\hline$A_{\mathrm{tz}}(\mathrm{cm} / \mathrm{s})^{\#}$ & $38.20(35.10-45.05)$ & $38.00(35.00-39.00)$ & 0.450 \\
\hline $\mathrm{E}_{\mathrm{tz}} / \mathrm{A}_{\mathrm{tz}}^{\#}$ & $1.40(1.30-1.57)$ & $1.50(1.25-1.70)$ & 0.660 \\
\hline $\mathrm{E}_{\mathrm{tz}} / \mathrm{e}^{\prime \#}$ & $5.77(4.45-6.70)$ & $5.20(3.53-5.85)$ & 0.299 \\
\hline $\mathrm{s}^{\prime}(\mathrm{cm} / \mathrm{s})^{\#}$ & $12.80(10.99-16.25)$ & $13.20(11.85-15.40)$ & 0.710 \\
\hline $\mathrm{e}^{\prime}(\mathrm{cm} / \mathrm{s})^{\#}$ & $9.80(8.05-11.95)$ & $11.60(8.44-16.15)$ & 0.187 \\
\hline$a^{\prime}(\mathrm{cm} / \mathrm{s})^{\#}$ & $13.90(12.25-16.55)$ & $12.80(11.50-15.10)$ & 0.270 \\
\hline$e^{\prime} / a^{\prime \#}$ & $0.60(0.49-0.70)$ & $0.88(0.55-1.23)$ & 0.008 \\
\hline DT $(\mathrm{ms})^{\#}$ & $201.00(155.50-245.00)$ & $187.00(159.00-232.00)$ & 0.682 \\
\hline $\mathrm{TR} V \max (\mathrm{cm} / \mathrm{s})^{\#}$ & $2.57(2.10-3.27)$ & $2.50(1.16-1.75)$ & 0.346 \\
\hline RVSP (mm Hg) & $33.06 \pm 10.08$ & $33.82 \pm 7.85$ & 0.786 \\
\hline $\mathrm{VCl}(\mathrm{cm})^{\#}$ & $1.60(1.40-1.70)$ & $1.50(1.15-1.75)$ & 0.554 \\
\hline PVR $\left(M P a \cdot s / m^{3}\right)^{\#}$ & $1.56(1.32-17.16)$ & $1.46(1.26-1.76)$ & 0.150 \\
\hline TEI index $\#$ & $0.30(0.30-0.45)$ & $0.40(0.30-0.45)$ & 0.559 \\
\hline
\end{tabular}

Data are presented as mean \pm Sd for continuous variables, or as absolute frequencies for categorical variables and compared by the Student's t-test or by the Chi-square test, respectively. \#Due to asymmetrical distribution, values are presented as median (interquartile range) and analyzed by the Mann-Whitney U-test.

patients and healthy controls. The two groups had similar distribution of gender, but patients were significantly older than controls. RV wall thickness was increased in patients, while $R V_{E S A}$ and $R V_{E D A}$ did not differ among the examinees. Similarly, we found no differences in the FAC, RA major-axis dimension and $\mathrm{E}_{\mathrm{tz}}$. In contrast, RA minor-axis dimension and TAPSE were significantly higher in SSc patients. $E_{t z} / A_{t z}$ ratio, $\mathrm{E}_{\mathrm{tz}} / \mathrm{e}^{\prime}$ ratio, s'velocity and a' velocity were significantly higher, while $E_{t z}, A_{t z}$ and $e^{\prime} / a^{\prime}$ ratio were lower in SSc patients than in controls. We found no differences in DT and TEI index, but TR Vmax, VCI, RVSP and PVR were significantly higher in SSc patients.

In addition, we compared the same parameters as in the previous analysis among limited cutaneous systemic sclerosis (LSSc) and diffuse cutaneous systemic sclerosis (DSSc) patients (Table II). Apart from the expected gender differences, all the other exam- ined parameters were uniform between the two groups of SSc patients, with the exception of the $e^{\prime} / a^{\prime}$ ratio which was significantly higher in LSSc patients.

Next, we analyzed differences in the concentrations of the brain natriuretic peptide (BNP) between DSSc and LSSc patients. As it can be seen in the Figure 1, DSSc patients had significantly higher concentrations of the BNP.

Based on the previous findings, we further explored the levels of BNP in SSc patients clustered by the results of capillaroscopy (Figure 2). The obtained results revealed that SSc patients with an early form of the disease had the lowest concentrations of BNP, whereas the levels of this marker increased in parallel with the disease progression. The patients with an early form of SSc had markedly lower concentrations of BNP than subjects with a late 


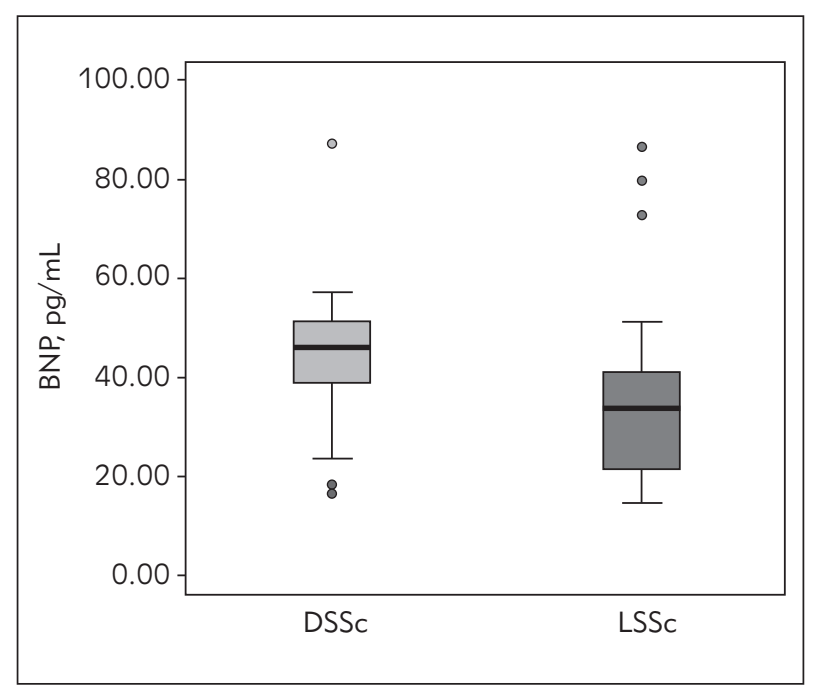

Figure 1 Concentrations of the brain natriuretic peptide (BNP) in DSSc and LSSc patients.

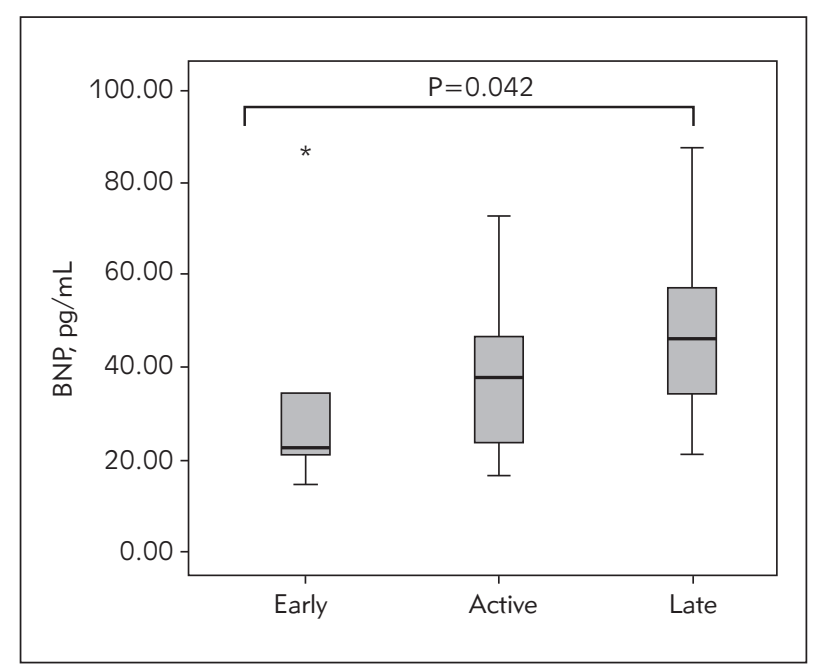

Figure 2 Concentrations of the brain natriuretic peptide (BNP) in SSc patients clustered by the results of capillaroscopy.

Data are compared by Kruskal-Wallis test, followed by post hoc Mann-Whitney U-test. Statistically significant differences were considered if $\mathrm{P}<0.017$, according to Bonferroni correction.

${ }^{*} \mathrm{P}=0.020$ for differences between early and late form of $\mathrm{SSc}$.

form, although with borderline significance (reached $P=0.020$ vs. $P<0.017$ according to Bonferroni adjustment). In order to explore whether the increase in BNP levels arises as a consequence of older age, we analysed the age differences between patients with the various forms of SSc. Our results have shown that there are no statistically significant differences among the observed groups of the patients with an early, active and late form of SSc (52.00 \pm 12.49 vs. $50.04 \pm 10.72$ vs. $54.27 \pm 9.38$ respectively, $P=0.561)$.
Table III Correlations of BNP with other examined parameters in patients with SSc.

\begin{tabular}{|l|c|c|}
\hline & $\begin{array}{c}\text { Spearman's } \\
\text { correlation coefficient }\end{array}$ & $P$ \\
\hline Age (years) & 0.417 & 0.007 \\
\hline Disease duration & 0.358 & 0.023 \\
\hline CRP $(\mathrm{mg} / \mathrm{L})$ & 0.348 & 0.032 \\
\hline FAC $(\%)$ & 0.366 & 0.022 \\
\hline $\mathrm{e}^{\prime} / \mathrm{a}^{\prime}$ & -0.389 & 0.013 \\
\hline $\mathrm{PVR}(\mathrm{MPa} \times \mathrm{s} / \mathrm{m} 3)$ & 0.323 & 0.042 \\
\hline Rodnan score & 0.368 & 0.019 \\
\hline
\end{tabular}

We found that levels of BNP were in significant positive correlations with age, disease duration, $C$ reactive protein (CRP), fractional area change (FAC), pulmonary vascular resistance (PVR) and Rodnan score, while in negative correlation with $\mathrm{e}^{\prime} / \mathrm{a}^{\prime}$ ratio.

\section{Discussion}

Cardiac involvement in SSc may be presented with various manifestations and is an indicator of a poor prognosis (2). Recent studies have suggested that the RV and left ventricle (LV) functions are reduced in patients with $\mathrm{SSc}$ and are associated with elevated morbidity (27-29). In our study, we compared the examined parameters of RV systolic function in SSc patients and healthy controls. Our results confirmed the previous findings, when it came to the RV wall thickness. Although in both groups the RV had an average wall thickness, the RV wall thickness was significantly higher in SSc patients. Right ventricular end-systolic area $\left(\mathrm{RV}_{\mathrm{ESA}}\right)$ and right ventricular end-diastolic area $\left(R V_{E D A}\right)$ did not differ among the examinees. We found no differences in the FAC. TAPSE were significantly higher in SSc patients. There were no differences in TEl index among the examinees. $s^{\prime}$ velocity was significantly higher in SSc patients than in healthy controls (Table I).

It has been proved that measures of RV systolic function such as TAPSE, $S$ velocity, FAC, and TEI index correlate with decreased survival $(27,29)$. In our study, we found no differences in the FAC and TEl index, while TAPSE and s' velocity were significantly higher in SSc patients than in healthy controls (Table I).

Parameters of the RV diastolic dysfunction are the $E_{t z} / A_{t z}$ ratio, $D T$, the $E_{t z} / e^{\prime}$ ratio, and $R A$ size. In our study, we investigated all these parameters. We found no differences in the RA major-axis dimension. In contrast, RA minor-axis dimensions were significantly higher in SSc patients. The $E_{t z}, A_{t z}$ and $e^{\prime} / a^{\prime}$ ratio were lower in SSc patients than in controls, while $\mathrm{E}_{\mathrm{tz}} / \mathrm{A}_{\mathrm{tz}}$ ratio, $\mathrm{E}_{\mathrm{tz}} / \mathrm{e}^{\prime}$ ratio, and $\mathrm{a}^{\prime}$ velocity were signifi- 
cantly higher. We found no differences in DT and $e^{\prime}$ velocity (Table I). It is known that the right atrial and $\mathrm{RV}$ chamber enlargement in SSc are directly related with the heart failure symptoms and mortality (3037). RA size is correlated with clinical outcomes in $\mathrm{PAH}$ (28). In our SSc population, the $\mathrm{E}_{\mathrm{tz}} / \mathrm{A}_{\mathrm{tz}}$ ratio was significantly higher than in healthy controls (Table I). This can be considered as an index of abnormal right ventricular relaxation. Another explanation is that it is an indicator of diastolic dysfunction, which is a more subtle disorder and occurs earlier.

Our results have not shown a correlation of the disease severity with the echocardiogram assessment of systolic function of the RV, which is not in accordance with the results of previous studies. In our study, RVSP and PVR were significantly higher in SSc patients, although values were in the normal range. This can be explained as an increased risk in these patients for the occurrence of PAH.

In a recent study, it has been shown that noninvasive measurements of PVR predict pulmonary arterial hypertension (PAH) in SSc (19). Guazzi et al. (32) reported that the TAPSE/systolic pulmonary artery pressure (SPAP) ratio improves the prognostic risk stratification in heart failure patients when compared to TAPSE alone and a ratio, $0.36 \mathrm{~mm} / \mathrm{mmHg}$ predicts higher mortality in such patients (32). The inferior vena cava was significantly higher in SSc patients. It is known that dilated IVC usually denotes elevated RA pressures, and the results in our study could be explained by the fact that the SSc patients have a higher risk for PAH.

In the next step, we compared parameters of RV function among subjects with limited and diffuse forms of scleroderma (Table II). According to our results, echocardiographic parameters were similar in SSc patients and healthy controls (38-40). Some studies have found that cardiac manifestations occur in both diffuse and limited cutaneous forms of SSc, whereas according to others, the prevalence is greater in the diffuse cutaneous form of the disease and the DSSc is associated with significant morbidity and mortality $(2,41)$.

Although echocardiographic markers failed to detect significant differences between DSSc and LSSc participants in our study, DSSc patients had significantly higher concentrations of BNP (Figure 1). Increased concentration of natriuretic peptides in the plasma may be associated with an increased risk of pulmonary hypertension, which arises as a consequence of RV dysfunction $(37,39)$. It has been previously demonstrated (15-17) that BNP might be useful in predicting cardiovascular outcome in SSc patients. In this study, we demonstrated that the laboratory determination of BNP can also be used as a tool in differentiating various types of SSc. Further- more, considering that the parameters of RV did not differ between the two forms of SSc in our study (Table II), the obtained results suggested that BNP might even be more sensitive for estimating possible cardiovascular complications in different forms of SSc. Such results emphasize the role of laboratory analyses in the treatment and follow-up of this particular group of patients.

To further extend our previous findings, we analysed the levels of BNP according to the disease extent and severity. According to our results, measuring of BNP in SSc patients could also be useful in the detection of disease severity (Figure 2). Interestingly, Elshamy et al. (42) demonstrated that NT-proBNP has potential in estimating SSc severity. Our results expand these previous findings by confirming that BNP can also be used for the same purposes. Such researches highlight the importance of cooperative activities in the diagnostics and follow-up of complex diseases.

Additionally (Table III), we found that BNP correlates with age and disease duration but also with Rodnan score, which is used as a sign of disease severity and mortality in DSSc patients (41). These results provide further strength to the proposed hypothesis regarding the role of BNP as SSc type and severity marker. It is known that the BNP is in negative correlation with FAC. In our study, levels of BNP were in significant positive correlations with FAC (Table III). Right ventricle is the main source of circulating BNP, and our results can be explained by the fact that the right heart failure has not developed in our patients.

Our study had several limitations. First, the number of patients included in the study was small. The reason for this is that SSc is a rare disease. Another potential limitation of our study was that it included the majority of patients with newly diagnosed SSc, but still there was no development of RV myocardial dysfunction. Moreover, the data on BNP levels in the control group are missing, so we could not compare BNP concentrations between the SSc patients and healthy individuals.

\section{Conclusion}

Notwithstanding the great progress in the treatment of patients with systemic sclerosis, the percentage of cardiovascular involvement in these patients is still relatively high.

Early detection of SSc in the period before significant manifestation to certain organs or systems is in the focus of many researchers. SSc is a lifelong disease and cannot be cured, but knowing that cardiac dysfunction significantly worsens the prognosis, early detection of cardiac complications and appropriate therapy can influence its progress and improve the 
quality of life for patients. Our findings that BNP is associated with the severity of the disease might suggest that BNP is a more sensitive marker than echocardiographic parameters for the evaluation of systolic function.

Given the obtained results, the laboratory determination of BNP could be useful in differentiating different forms of systemic sclerosis as well as in pre-

\section{References}

1. Cutolo $M$, et al. Nailfold capillaroscopic patterns and serum antibodies in systemic sclerosis. Rheumatology 2004; 43: 719-26.

2. Lambova S. Cardiac manifestations in systemic sclerosis. World J Cardiol 2014; 6(9): 993-1005.

3. Plazak W, Zabinska-Plazak E, Wojas Pelc A, Podolec P, Olszowka M, Tracz W, et al. Heart structure and function in systemic sclerosis. Eur J Dermatol 2002; 12: 257-62.

4. D'Andrea A, D'Alto $M$, Di Maio M, Vettori S, Benjamin N, Cocchia R, Argiento P, Romeo E, Di Marco G, Russo MG, Valentini G, Calabrò R, Bossone E, Grünig E. Right atrial morphology and function in patients with systemic sclerosis compared to healthy controls: a two-dimensional strain study. Clin Rheumatol 2016 Jul; 35(7): 173342. doi: 10.1007/s10067-016-3279-9. Epub 2016 Apr 27.

5. Karna SK, Rohit MK, Wanchu A. Right ventricular thickness as predictor of global myocardial performance in systemic sclerosis: A Doppler tissue imaging study. Indian Heart J 2015 Nov-Dec; 67(6): 521-8. doi: 10.1016/j. ihj.2015.06.021.

6. Hassoun PM. The right ventricle in scleroderma (2013 Grover Conference Series). Pulm Circ 2015 Mar; 5(1): 3-14. doi: 10.1086/679607.

7. Varga J, Denton CP, Wigley FM. Scleroderma. New York: Springer, 2012: 361-71; 373-95.

8. Dinser R, Frerix M, Meier FM, Klingel K, Rolf A. Endocardial and myocardial involvement in systemic sclerosis - is there a relevant inflammatory component? Joint Bone Spine 2013; 80: 320-323 [PMID: 23238003 DOI: 10.1016/j.jbspin.2012.10.009].

9. Kahan A, Allanore Y. Primary myocardial involvement in systemic sclerosis. Rheumatology (Oxford) 2006; 45 (Suppl. 4), iv14-7.

10. Ferri C, Valentini G, Cozzi F, et al. Systemic sclerosis: demographic, clinical, and serologic features and survival in 1,012 Italian patients. Medicine 2002; 81: 139-53.

11. Kossaify A. Echocardiographic Assessment of the Right Ventricle, from the Conventional Approach to Speckle Tracking and Three-Dimensional Imaging, and Insights into the "Right Way" to Explore the Forgotten Chamber. Clinical Medicine Insights: Cardiology 2015: 9 65-75 doi: $10.4137 / C M C . S 27462$.

12. Valsangiacomo Buechel ER, Mertens LL. Imaging the right heart: the use of integrated multimodality imaging. Eur Heart J 2012; 33(8): 949-60. dicting the severity of the disease and future cardiovascular complications.

\section{Conflict of interest statement}

The authors stated that they have no conflicts of interest regarding the publication of this article.

13. Apostolakis S, Konstantinides S. The right ventricle in health and disease: insights into physiology, pathophysiology and diagnostic management. Cardiology 2012; 121(4): 263-73.

14. Galie N, Hoeper MM, Humbert M, et al. Guidelines for the diagnosis and treatment of pulmonary hypertension: the Task Force for the Diagnosis and Treatment of Pulmonary Hypertension of the European Society of Cardiology (ESC) and the European Respiratory Society (ERS), endorsed by the International Society of Heart and Lung Transplantation (ISHLT). Eur Heart J 2009; 30, 2493-537.

15. Allanore $\mathrm{Y}$, Meune $\mathrm{C}$. N-terminal pro brain natriuretic peptide: the new cornerstone of cardiovascular assessment in systemic sclerosis. Clin Exp Rheumatol 2009; 27: 59-63.

16. Voilliot D, Magne J, Dulgheru R, Kou S, Henri C, Caballero L, De Sousa C, Sprynger M, Andre B, Pierard LA, Lancellotti P. Cardiovascular outcome in systemic sclerosis. Acta Cardiol 2015; 70: 554-63.

17. Giallafos I, Triposkiadis F, Oikonomou E, Giamouzis G, Aggeli K, Konstantopoulou P, Kouranos V, Mavrikakis M, Giallafos J, Stefanadis C, Sfikakis PP. Incident atrial fibrillation in systemic sclerosis: the predictive role of B-type natriuretic peptide. Hellenic J Cardiol 2014; 55: 313-21.

18. Valentini G, et al. Ann Rheum Dis 2017; 76: 270-6. doi: 10.1136/annrheumdis-2016-209768.

19. Mukherjee $M$, et al. Right Ventricular Strain in Systemic Sclerosis. Circ Cardiovasc Imaging 2016; 9: e003792. DOI: 10.1161/CIRCIMAGING.115.003792.

20. Tavakol ME, Fatemi A, Karbalaie A. Nailfold Capillaroscopy in Rheumatic Diseases: Which Parameters Should Be Evaluated? Biomed Res Int 2015; 2015: 974530.

21. Herrick AL, Cutolo M. Clinical implications from capillaroscopic analysis in patients with Raynaud's phenomenon and systemic sclerosis. Arthritis Rheum 2010; 62: 2595-604.

22. Cutolo M, Sulli A, Pizzorni C, et al. Nailfold videocapillaroscopy assessment of microvascular damage in systemic sclerosis. J Rheumatol 2000; 27: 155160.

23. Cutolo M. Capillaroscopy links to clinical pathological issues in systemic sclerosis. In: Tolo M. Atlas of Capillaroscopy in Rheumatic Diseases. Elsevier, Milan 2010: 173-9. 
24. Van den Hoogen F, Khanna D, Fransen J. 2013 classification criteria for systemic sclerosis: an American College of Rheumatology/ European League against Rheumatism collaborative initiative. Arthritis Rheum 2013; 65: 2737-47.

25. Khanna D, Merkel P. Outcome measures in systemic sclerosis: an update on instruments and current research. Curr Rheumatol Rep 2007; 9: 151-7.

26. Clements PJ, Hurwitz EL, Wong WK, et al. Skin thickness score as a predictor and correlate of outcome in systemic sclerosis: high-dose versus low-dose penicillamine trial. Arthritis Rheum 2000; 43: 2445-54.

27. Frea S, Capriolo M, Marra WG, Cannillo M, Fusaro E, Libertucci D, Morello M, Gaita F. Echo Doppler predictors of pulmonary artery hypertension in patients with systemic sclerosis. Echocardiography 2011; 28: 860-9. doi: 10.1111/j.1540-8175.2011.01467.x.

28. Haeck ML, Scherptong RW, Marsan NA, Holman ER, Schalij MJ, Bax JJ, Vliegen HW, Delgado V. Prognostic value of right ventricular longitudinal peak systolic strain in patients with pulmonary hypertension. Circ Cardiovasc Imaging 2012; 5: 628-36. doi: 10.1161/ CIRCIMAGING.111.971465.

29. Mathai SC, Sibley CT, Forfia PR, Mudd JO, Fisher MR, Tedford RJ, Lechtzin N, Boyce D, Hummers LK, Housten T, Zaiman AL, Girgis RE, Hassoun PM. Tricuspid annular plane systolic excursion is a robust outcome measure in systemic sclerosis-associated pulmonary arterial hypertension. J Rheumatol 2011; 38: 2410-28. doi: 10.3899/jrheum.110512.

30. Rudski LG, et al. Guidelines for the Echocardiographic Assessment of the Right Heart in Adults: A Report from the American Society of Echocardiography Endorsed by the European Association of Echocardiography, a registered branch of the European Society of Cardiology, and the Canadian Society of Echocardiography. J Am Soc Echocardiogr 2010; 23: 685-713.

31. Hachulla E, Launay D, Yaici A, Berezne A, de Groote P, Sitbon O, Mouthon L, Guillevin L, Hatron PY, Simonneau G, Clerson P, Humbert M; French PAH-SSc Network. Pulmonary arterial hypertension associated with systemic sclerosis in patients with functional class II dyspnoea: mild symptoms but severe outcome. Rheumatology (Oxford) 2010; 49: 940-4. doi: 10.1093/rheumatology/kep449.

32. Guazzi M, Bandera F, Pelissero G, et al. Tricuspid annular plane systolic excursion and pulmonary arterial systolic pressure relationship in heart failure: an index of right ventricular contractile function and prognosis. Am J Physiol Heart Circ Physiol 2013; 305(9): H1373-81.
33. Kopecna D, Briongos S, Castillo $\mathrm{H}$, et al; PROTECT investigators. Interobserver reliability of echocardiography for prognostication of normotensive patients with pulmonary embolism. Cardiovasc Ultrasound 2014; 12: 29.

34. Petrovic I, Stankovic I, Milasinovic G, Nikcevic G, Kircanski B, Jovanovic V, Raspopovic S, Radovanovic N, Pavlovic SU. The relationship of myocardial collagen metabolism and reverse remodeling after cardiac resynchronization therapy. J Med Biochem 2016; 35; 130-6.

35. Desai CS, Lee DC, Shah SJ. Systemic sclerosis and the heart: current diagnosis and management. Curr Opin Rheumatol 2011; 23: 545-54. doi: 10.1097/BOR. Ob013e32834b8975.

36. Elhai M, Meune C, Avouac J, Kahan A, Allanore Y. Trends in mortality in patients with systemic sclerosis over 40 years: a systematic review and meta-analysis of cohort studies. Rheumatology (Oxford) 2012; 51: 1017-26. doi: 10.1093/rheumatology/ker269.

37. Hsu VM, Moreyra AE, Wilson AC, Shinnar M, Shindler DM, Wilson JE, Desai A, Seibold JR. Assessment of pulmonary arterial hypertension in patients with systemic sclerosis: comparison of noninvasive tests with results of right-heart catheterization. J Rheumatol 2008; 35: 45865.

38. Grünig E, Henn P, D'Andrea A, et al. Reference values for and determinants of right atrial area in healthy adults by 2-dimensional echocardiography. Circ Cardiovasc Imaging 2013; 6(1): 117-24.

39. Besedina A. No-synthase activity in patients with coronary heart disease associated with hypertension of different age groups. J Med Biochem 2016; 35: 43-9.

40. McLaughlin VV, Archer SL, Badesch DB, et al. ACCF/ AHA 2009 expert consensus document on pulmonary hypertension, a report of the American College of Cardiology Foundation Task Force on Expert Consensus Documents and the American Heart Association developed in collaboration with the American College of Chest Physicians; American Thoracic Society, Inc.; and the Pulmonary Hypertension Association. J Am Coll Cardiol 2009; 53: 1573-619 [PMID: 19389575 DOI: 10.1016/j. jacc.2009.01.004].

41. Amjadi S, et al. Course of Modified Rodnan Skin Score in Systemic Sclerosis Clinical Trials: Analysis of 3 Large Multicenter, Randomized Clinical Trials. Arthritis Rheum 2009 August; 60(8): 2490-8. doi: 10.1002/art.24681.

42. Elshamy HA, Ibrahim SE, Farouk HM, Moustafa AA, Aly IM, Osman WM. N-terminal pro-brain natriuretic peptide in systemic sclerosis: new insights. Eur J Dermatol 2011; 21: 686-90. 